\title{
Understanding Tradition of American Jewish Writing Canon
}

\author{
Dr. Prerna Malhotra
}

Assistant Professor, Department of English, Ram Lal Anand College, University of Delhi

E-mail: prernavmalhotra@yahoo.co.in

\begin{abstract}
The much-eventful twentieth century is often termed as 'the American Century' due to the American pervasiveness in the global affairs. The Americanness is present through American arts, culture and literature written during the end of the $19^{\text {th }}$ century to most part of the $20^{\text {th }}$ century. The experience of two world wars, the cold war, the beginning of the nuclear arms race, the realisation of the struggle for national liberty by the colonised world and lack of socio-political consensus within nations everywhere have had a direct impact on the literature during this period. Phrases, like modernism, war literature, post-modernism, existentialism and surrealism, etc. have been used in view of the attributes assigned to various traditions of literature. Themes too have covered the breadth and depth of multic ulturalism and diversity. Voices unheard till now started coming in the form of ethnic literature, Black literature and literature by natives. It is in this context that this article tries to analyse the tradition of American Jewish writings.

Keywords-Canon, Modern, Post-modern, American Literature, Jewish literature, Commonwealth literature, Genre, World cultures.
\end{abstract}

\section{INTRODUCTION}

Humanity has gone through tremendous turmoils and transformation, specifically in the twentieth century. Such makeover in accepted wisdom has produced individuals who do not conform to collective sensibilities. The end result is that the narrative in English is no more a generalised trend or feature especially since World War II. It has become variegated and multifaceted, therefore, even broad generalizations as literary critics are accustomed to doing, like Modern, Post-modern; Structural, Post-structural; Colonial, Post-colonial seem to have narrow precincts and are unable to carry the width and variety of narration. In addition to that, the narration has been vitalized by international currents such as European existentialism, Latin American magical realism. Commonwealth literature and particularly the writers of Indian origin are incessantly trying to make a strong niche for themselves on the English literary scene. On the other hand, the electronic era has made the global village an actuality, the spoken word on television has given new life to oral belief and with the world-wide web, writing has become all the more universal as it instantly influences and is influenced. Translation has become a vital tool to reach the cultural, educational and literary interiors and by-lanes of the globe.

But by looking at such diversified patterns of English literature, one is not belittling or trivializing recent literature. Today writers in the world, especially in the
United States are asking grave questions, many of them related to the very existence of humanity, the positioning of humans in the universe. Metaphysical queries have become frequent occurring in literature. Writers have become highly inventive and novel and self-awareness has crept in their sensibilities. Many a times, they find traditional modes unproductive and seek liveliness in more widely trendy material. To put it another way, modernist restructurings of point of view no longer meet their requirements rather they are looking for special type of sensibilities which are termed as post-modern sensibilities.

Differentiating Post-modern from Modern, Richard Allen writes: "Perhaps the most significant feature of postmodernist thought concerns the limitations on human knowledge of truth and reality, and the realm of uncertainty into which those restrictions place us...Postmodernism distinguishes itself from modernism largely in terms of tone, audience and political orientation."1

If we talk of the $21^{\text {st }}$ century English literary scenario, the literary critics have come forth with their logic and viewpoint that even the days of Post-modernism are over, i.e. post- Post modernism has paved its way in English literary criticism.

\footnotetext{
${ }^{1}$ Schwartz, Richard Allen. "Postmodernist Baseball," in Modern Fiction Studies, Vol.33, No.1, Spring 1987, pp.135-36.
} 
Now coming back to the World War II scene and the literature after that, the whole world and particularly the United States had come out of the Depression and the 1950s provided most Americans with time to get pleasure from welcomed material riches. Yet alienation and loss of belongingness were the foremost themes and the writers explored the pressures lurking in the shades of outward fulfillment.

Many outstanding works of the period like Arthur Miller's Death of a Salesman, John Osborne's Look Back in Anger and Samuel Becket's Waiting for Godot depict humans who fail in the struggle to succeed, who have secession from society, thus, have identity crisis. It is noteworthy that it has been a generation of writers who have behind them the destruction and the old order of things. When they look around themselves, the old order and traditional values have not yet given place to the new. They believe that man's identity and even masculinity has been eroded and he does not enjoy the status of the normative centre of the universe.

These are the basic themes which are, mainly or remotely, dealt in the writings of Ralph Ellison, Saul Bellow, John Updike, Norman Mailer, Philip Roth, Cynthia Ozick, John Hawks etc. Saul Bellow's Henderson, The Rain King, Percy's Lancelot and Malamud's The Natural and A New Life depict the quest of the contemporary man. Themes of man's dilemma and loneliness have been dealt exquisitely in their writings by incorporating new techniques and devices. Alienation, in one form or the other, has been creeping as an under-current. Subsequently it got manifested at all possible opportunities in the main current of English literature.

It was in those years that a new sub-genre of writing, American Jewish Writing, came up as a movement along with so many other ethnic and gender related movements. Writers like Saul Bellow, Bernard Malamud, Philip Roth, John Updike, Cynthia Ozick, Norman Mailer and Is aac Bashevis Singer belong to that sub-genre and are the prominent, worthy and compelling additions to the compendium of American literature. The output of these authors is best noted for its humour, ethical concern, and portraits of Jewish communities in the Old and New Worlds.

Along with Saul Bellow and Philip Roth, Malamud has remained a legendary charisma during the peak period of American Jewish renaissance, i.e. 1960s to 1970s. His stories found place in the acclaimed literary magazines and today his awards and honours make for an impressive paragraph on all major web search engines and literary encyclopedias. Even after their deaths, writers like Bellow and Malamud, continue to be read and enjoyed. In fact, their reputation is steadily growing as students are introduced to their works and many of the degree holders in English literature owe their degrees to them. Moreover, the general interest in ethnicity draws readers to Jewish literature, where they discover that Bellow, Malamud, Ozick and Singer, to name a few, speak to all sensitive, intellectual readers.

Here the mention must be made to the fact that Cynthia Ozick presents a kind of contrast to her contemporaries like Bellow, Malamud or Roth. If these male Jewish writers are the advocates of assimilation and western humanism, Ozick is a promoter of the thought that Jewish heritage must be preserved in the prevailing Gentile culture.

In fact, many critics have been uncomfortable and confused with the 'clumsy' term itself- 'AmericanJewish'. Sanford considers that it makes more sense to talk about literature in Hebrew or Yiddish but there should not be any such term like Jewish literature:

"Strictly speaking, there is no "Jewish" literature. Rather, the "Jewishness" is a matter of content: a commentary on the Talmand or homilectics about Tanakh would qualify, but not the stories of people like Bernard Malamud or Saul Bellow or even Isaac Bashevis Singer. Theirs is a writing which tends to distractrather than enhance the study of sacred texts. And to the devoutly religious, this is called bittel Torah, a waste of time."2

Some other critics also believe that Malamud and Bellow are not Jewish writers per se, as expresses Schulz, "...Bernard Malamud and Saul Bellow, transcend the specific Jewish context of their tales. Ultimately their response is to man, rather than to Jew, to the human dilemma rather than to the Jewish paradox." 3

In interviews, Malamud has credited his painstaking "Yiddish" parents and their Eastern European immigrant generation providing with models of morality but he has emphasized that humanity is his subject and he uses Jews to communicate the universal just as William Faulkner created a universe from a corner of the American South. In an interview in 1976 when Malamud was asked the question for whom did he write, his answer was: "I write

\footnotetext{
2 Pinkser, Sanford. (1980). "The Rise and Fall of the American Jewish Novel," Between Two Worlds-- The American Novel in the 1960s. New York: Whitson Publishing Co. Troy. p.29.

${ }^{3}$ Schulz, max F. (1969). Radical Sophistication: Studies in Contemporary Jewish American Novelists. Ohio: Ohio Univ. Press, p. VIII of Preface.
} 
for anyone who can read. I write for Indians, Japanese, Hungarians, British - any one who can read." 4

What is so peculiar and appealing about Malamud is that in spite of various influences on him, he is not just a follower or adherent of those thoughts. His appeal is very general as the questions he poses through his fiction are fundamental questions, related to mankind. They are questions posed since times immemorial- why should one follow goodness when righteousness goes unrewarded most of the time? How many times is it that love begets love and not violence and hatred? Then how can and why should one continue flowing with the milk of human love and kindness? Why a senior Morris Bober paves the way for a junior Morris?

Malamud's remarkable and monumental work is The Fixer for which he was awarded the Pulitzer Prize and National Book Award. First of all, this is the novel which deals directly with the theme of Jewishness and pogroms and anti-Semite activities. It is also different from other novels as it is set in Russia, not America and also it is based on an actual historical trial of a Jew around the turn of the 20th century. The infamous 1913 trial of Mendel Beliss is a blotch on modern history and one of the infamous incidents whish led to the Revolution of 1917. In fact, through this novel Malamud has entered into a kind of dialogue with traditional Jewish resources. It is in this novel that Malamud seems to ask the fundamental question related to the survival of Jews in the PostHolocaust period. The same question is put forward through Saul Bellow's Mr. Sammler's planet and Edward Lewis Wallant's The Pawnbroker-how can the teachings of Judaism help the Jews to confront the fundamental question related to their identity.

These are the fundamental questions which have persistently appeared in Malamud fiction. Throughout his life, as a human, a writer as well as a teacher, he has been fighting within himself to find an answer to these pertinent queries. Both as a novelist and a short story writer, Malamud, gifted as a genuine writer, has been unflaggingly dedicated to his craft but even his whole life has not been sufficient for this assignment, as he spoke about it at length in a talk:

"I don't regret the years I put into my work. Perhaps I regret the fact that I was not two men, one who could live a full life apart from writing; and one who lived in art, exploring all he had to experience and know how to make his work

\footnotetext{
${ }^{4}$ Masilamoni, Leelavathi E. H. "Bernard Malamud- An Interview," IJAS, V.9, No.2, July 1979. p.33.
}

right; yet not regretting that he had put his life into the art of perfecting the work" 5

Perhaps Noman Podhoretz is very right when he sums up the author, "His work, when it is good- which sufficiently often it is- seems a kind of miracle, an act of spiritual autonomy, perfect enough to persuade us that the possibility of freedom from the determining of history and sociology still exists." 6

If Malamud is critical of the milieu, at the same time, he indicates towards the inane goodness of man and his desire to be better placed than his present lot but he can succeed only if he kills his enemy within in the form of greed and selfishness and then, of course, society can do little to thwart his goodness.

\section{CONCLUSION}

Cultural battles and diverse conflicts have been fought through ethnic American literature, the prominent among them being Jewish American literature. Yet, individualism and multiculturalism of writers have ensured that the canon is a part of the wider sea of world cultures and literatures.

\section{REFERENCES}

[1] --------"Reflections of a Writer: Long Work, Short Life," March 20, 1988, Sunday, Late City Final Edition Section 7; Page 15, Column 1; Book Review Desk. (Based on Bernard Malamud's talk at Bennington College on Oct. 30, 1984, as part of the Ben Belitt Lectureship Series.)

[2] Bellow, Saul. (1963). Recent American Fiction, Washington. The Library of Congress, p.12.

[3] Beym, N. (2008) The Norton Anthology of American Literature, shorter $7^{\text {th }}$ Ed. Vol. 2, New York, NY:W.W.Norton \& Co.

[4] Chametzky, Jules. (2000) Jewish American Literature: A Norton Anthology, Ed. 1, New York, NY:W.W.Norton \& Co.

[5] Bluefarb, Sam. (1975). "The Syncretism of Bernard Malamud," Bernard Malamud: A Collection of Critical Essays. Edited by Leslie A. Field and Joyce A. Feild. Englewood Cliffs, N.J.: Prentice-Hall, pp. 72-79.

[6] Wershba, Joseph. "Not Horror but 'Sadness'," New York Post, Sept. 14, 1958, p.M2.

5 -------“"Reflections of a Writer: Long Work, Short Life," March 20, 1988, Sunday, Late City Final Edition Section 7; Page 15, Column 1; Book Review Desk. (Based on Bernard Malamud's talk at Bennington College on Oct. 30, 1984, as part of the Ben Belitt Lectureship Series.)

${ }^{6}$ Podhoretz, Norman. "The New Nihilism in the American Novel,” Partisan Review, XXV (Fall, 1958), p. 590. 